\title{
Ecology, Systematics and Biogeographical Relationships of Dinosaurs, Including a New Theropod, from the Santana Formation (?Albian, Early Cretaceous) of Brazil
}

\author{
DARREN NAISH ${ }^{\mathrm{a}, *}$, DAVID M. MARTILL ${ }^{\mathrm{a}}$ and EBERHARD FREY ${ }^{\mathrm{b}}$ \\ ${ }^{a}$ School of Earth and Environmental Sciences, University of Portsmouth, Portsmouth PO1 3QL, UK; \\ ${ }^{\mathrm{b}}$ Staatliches Museum für Naturkunde Karlsruhe, Geowissenschaftliche Abteilung, Erbprinzenstraße 13, D-76133 Karlsruhe, Germany
}

\begin{abstract}
Although rare, dinosaurs are well preserved in calcareous nodules of the Santana Formation (Early Cretaceous, ?Albian) of the Araripe Basin, in northeastern Brazil. So far, including only a spinosauroid and three coelurosaurs, the dinosaur fauna appears depauperate. High theropod diversity in assemblages where other dinosaurs are rare or absent is not unique to the Santana Formation. It is seen also in several other assemblages, including Solnhofen and the Maevarano Formation of Madagascar. We consider several factors, including the occurrence of intraguild predation, the possibility that small theropods could subsist in marginal environments, and reliance on coastal resources, that may have been responsible for this apparent ecological imbalance. A new coelurosaur from the Santana Formation, here formally named Mirischia asymmetrica, is shown to be distinct from Santanaraptor placidus [Kellner, A.W.A. (1999) "Short note on a new dinosaur (Theropoda, Coelurosauria) from the Santana Formation (Romualdo Member, Albian) northeastern Brazil", Boletim do Museu Nacional, Nova Serie, Rio de Janeiro, Brasil 49, 1-8]. Other theropods from the Santana Formation are briefly reviewed. Mirischia is a compsognathid, more similar to the European Compsognathus than to the Asian Sinosauropteryx.
\end{abstract}

Keywords: Dinosaur; Theropoda; Compsognathidae; Mirischia; Brazil; Santana Formation

\section{INTRODUCTION}

The calcareous nodule bearing Romualdo Member of the Santana Formation, in the Araripe Basin of northeastern Brazil, is the world's première source of Early Cretaceous pterosaurs. It has yielded a diverse and exceptionally well preserved assemblage (Martill and Unwin, 1989; Kellner and Tomida,
2000). It is less well known that this deposit also produces rare dinosaur remains (Campos and Kellner, 1991; Frey and Martill, 1995; Kellner, 1996a). Crocodyliforms and turtles also occur (Gaffney and Meylan, 1991; Martill, 1993; Hirayama, 1998), but these are rare. Perhaps surprisingly, the initial discovery of these tetrapod remains was an incidental result of commercial excavation of Romualdo nodules for their abundant and diverse fossil fishes. Previously, artisan fossil diggers had disposed of tetrapod remains which they considered to be of little or no commercial value. Since the 1980s this situation has changed. Now, tetrapod-bearing nodules, even those containing isolated or fragmentary elements, have begun to attract high prices.

Several nodules containing dinosaur remains have been documented, although not all have been described in full, as noted by Kellner (2001). Complete skeletons have not yet been reported, but partial skeletons in exceptional states of preservation are known (Kellner, 1996a,b; Martill et al., 2000). Bones within the nodules are usually preserved in three-dimensions, without flattening, sometimes in articulation (Martill et al., 2000). Soft tissue preservation has been reported (Kellner, 1996a,b; 1999) and gut contents were discovered in the theropod specimen described here (Martill et al., 2000).

The dinosaur fauna of the Romualdo Member is incompletely known, due to the small data set so far available, but the assemblage is clearly dominated by theropods. The first report of a noncrocodyliform, non-pterosaurian archosaur from the nodules was an isolated bone, tentatively identified as an ornithischian ischium (Leonardi and Borgamanero, 1981). This identification is

${ }^{*}$ Corresponding author. E-mail: darren.naish@port.ac.uk 
doubtful; Kellner (1996a; 1999) treated the specimen as Dinosauria incertae sedis. To date, this specimen is the only indication that ornithischians may be represented in the Santana dinosaur assemblage. However, apparently undiagnostic dinosaur material has also been reported by Campos (1985).

More readily identifiable remains were figured by Campos and Kellner (1991) in a short review of the Santana Formation dinosaurs. These authors figured, but did not describe, a number of new specimens. Beginning in the mid-1990s, several theropods were reported and described. Among the first of these was the partial sacrum of a coelurosaur, described by Frey and Martill (1995). They suggested, on the basis of its pleurocoelous centra, that it had affinities with Oviraptorosauria. With respect to this identification, Makovicky and Sues (1998) noted that pleurocoelous sacral centra occur in theropods other than oviraptorosaurs. They argued that the dorsally arched long axis and expanded intercentral articulations of the Santana specimen suggest that it is not an oviraptorosaur. Although there may be insufficient grounds, at present, to refer this sacrum to Oviraptorosauria with any degree of certainty, it does resemble the sacrum of the caenagnathid Chirostenotes (Currie and Russell, 1988; Sues, 1994). The main difference between them is the absence of a neural spine lamina in the Santana specimen. The suggestion that the Santana specimen represents an alvarezsaurid (Marjanovic, 2000) is without foundation. This specimen lacks the distinctive transversely compressed, procoelous sacral centra that are characteristic of that group.

The first named Santana theropod, Irritator challengeri, was described by Martill et al. (1996) on the basis of a partial skull, missing the end of its snout. Irritator was initially referred to Bullatosauria, a group erected by Holtz (1994) to include troodontids and ornithomimosaurs, but not supported as monophyletic by more recent analyses (Makovicky and Sues, 1998; Holtz, 2000). However, the presence in Irritator of straight, conical, unserrated tooth crowns patterned with vertical ridges, caudally located nares and other features indicate that it is a spinosauroid (Kellner, 1996a; Charig and Milner, 1997; Sereno et al., 1998). Further preparation of this specimen has now been completed and a more detailed description was recently published (Sues et al., 2002).

Kellner and Campos (1996) described a second Santana spinosauroid based only on a portion of distal rostrum; they named it Angaturama limai. While there is no overlap of corresponding structural elements between the holotypes of Irritator and Angaturama, they are similar in their degree of lateral compression, both possess a dorsal midline crest, and both have transversely round tooth crowns with unserrated carinae (Kellner and Campos, 1996; personal observations). Consequently, Charig and Milner (1997) and Sereno et al. (1998) suggested that Angaturama might be a junior synonym of Irritator. Holtz (1998) even suggested that the distal rostrum of Angaturama might fit on the end, as the missing rostrum of the holotype of Irritator. The discovery of another Santana spinosauroid specimen has recently been announced (Kellner, 2001). This appears to be the most complete Santana dinosaur yet discovered. Reportedly, it includes a complete pelvis and sacrum, caudal vertebrae, and incomplete front and hindlimbs.

Another coelurosaur from the Santana Formation, Santanaraptor placidus, was described by Kellner (1999). The specimen consists of an associated partial pelvis, hindlimb elements and vertebrae. It exhibits extensive preservation of soft tissues, including muscle fibres (Kellner, 1996b). As noted by Kellner (1999), the proximodistally large, U-shaped obturator notch of Santanaraptor indicates that this is a maniraptoriform coelurosaur. However, contra Kellner $(1999 ; 2001)$, this character is not diagnostic for Santanaraptor. Similar ischial obturator notches are widely distributed among other maniraptoriforms, including oviraptorosaurs and deinonychosaurs. Similarly, the foramen on the base of the lesser trochanter, regarded as diagnostic for Santanaraptor by Kellner (1999), is not unique to this taxon (Naish, 2000). Other diagnostic characters of Santanaraptor have been recognized, however, so we agree that this is a distinct, diagnosable taxon. Kellner (2001) has recently suggested inclusion of Santanaraptor within Tyrannoraptora, a maniraptoriform group erected by Sereno (1999) to include tyrannosauroids, oviraptorosaurs and paravians. This assignment is based on the unfooted distal ischium of Santanaraptor. However, the polarity of this character is undetermined at present, as argued by Holtz (2000). It is possible that the ischial foot was lost several times in the evolution of maniraptoriforms. It is also clear from conflicting coelurosaur phylogenies that Sereno's (1999) groupings are controversial and at odds with results of other studies (Makovicky and Sues, 1998; Padian et al., 1999; Holtz, 2000).

Martill et al. (2000) described another small coelurosaur from a Santana Formation nodule. In this specimen, the nearly complete pelvis, both femora, proximal parts of a tibia and fibula and several gastralia are preserved in articulation. In addition, the specimen included material filling the gut and a post-pubic air sac may be preserved. The osteology and soft tissues of this specimen were described by Martill et al. (2000), but it was not named, and neither its palaeoecological nor phylogenetic significance was discussed.

This specimen clearly represents a taxon, named here as a new genus and species, that is distinct from both previously described Santana coelurosaurs. 
The excellent preservation and intriguing osteology of this specimen have caused it to become integral to our understanding of theropod pelvic and hindlimb morphology (Hutchinson, 2001a,b), soft tissue biology and physiology (Paul, 2001) and the interpretation of less complete remains representing similar taxa (Naish et al., 2001).

\section{Why Only Theropods?}

The Santana Formation's dinosaur assemblage is unusual in that only theropods have been recorded. There is evidence that ornithopods may have been present in northeastern Brazil during the Early Cretaceous. Footprints from the Rio de Peixe Basin of Paraiba, some $100 \mathrm{~km}$ to the north-east of the Araripe Basin, have been attributed to hypsilophodontids (Leonardi, 1987; Leonardi et al., 1987).

The Romualdo Member was deposited under brackish or quasi-marine conditions. It represents either a lagoonal setting or a basin with only restricted connections to waters of normal marine salinity (Maisey, 1991; Martill, 1993). The dinosaur fauna is allochthonous and may have been derived from nearby shoreline environments. Transport distances are likely to have been in the order of tens of kilometres or less. The distance from Santana do Cariri to the nearest mapable shoreline is about $13 \mathrm{~km}$. We infer that all the dinosaur fossils represent remains of drifting carcasses, derived from the shoreline or swept out to sea from the mouths of rivers.

The environment surrounding the Araripe Basin is generally considered to have been arid or semi-arid. Thick sequences of evaporites occur in the Ipubi Formation, immediately below the Santana Formation. By far the most abundant fossils in the concretions of the Romualdo Member are fishes; several mass mortality horizons are recorded (Martill, 1988a; 1993). The flora consists largely of plants of a xerophytic nature. It is dominated by the gymnosperm Brachyphyllum, which had succulent leaves, and cycadiales (Crane and Maisey, 1990). The local terrestrial environment appears to have been sparsely vegetated and thus unable to support large numbers of herbivores. In these circumstances, predatory theropods would have been able to gain sustenance by scavenging along the shoreline, as well as by foraging in shallow water. It has been suggested that the spinosauroid Baryonyx was at least in part piscivorous (Charig and Milner, 1997). If this was so, it is equally plausible that the Santana spinosauroid Irritator was also facultatively piscivorous. We favour the view that Irritator was a generalist carnivore, preying on aquatic and terrestrial vertebrates as well as carrion, around the shoreline of the Santana lagoon. Theropods scavenging at the shoreline and fishing in shallow water would have stood a far greater chance of being incorporated into the Santana sediments than any herbivores feeding in the hinterland.

There are other dinosaur assemblages that are notable for their abundance of theropods relative to herbivorous taxa. The extreme case is that of the Solnhofen Limestone (Kimmeridgian-Tithonian), in which the only dinosaurs preserved are the small theropods Archaeopteryx, Wellnhoferia (Elzanowski, 2001), Compsognathus and an unnamed form (Viohl, 1999). The Aptian/Albian to Cenomanian dinosaur-bearing sequences of North Africa yield more theropod remains than herbivores, although quantitative data are not available (Russell, 1996). In the Grès Rouges of Tafilalt, Morocco, theropods outnumber sauropods and ornithischians are absent, with the exception of a possible stegosaur (Russell, 1996). In the Wadi Milk Formation of Sudan, iguanodontids and hypsilophodontids are present but they appear to be rare compared with theropods and sauropods (Rauhut, 1999). In both the Maevarano Formation (Maastrichtian) of Madagascar and the Sao Khua Formation (Lower Cretaceous) of Thailand, the dinosaur assemblages are likewise dominated by theropods and sauropods (Sampson et al., 1998; Buffetaut and Suteethorn, 1999; Krause et al., 1999), while ornithischians are absent. The Santana dinosaur assemblage differs from those of Tafilalt, Sudan, Madagascar and Thailand in that no herbivores have yet been recorded. In this respect, it recalls the Solnhofen fauna.

A number of speculative scenarios have been advanced to explain the diversity of theropods in some of these faunas. Russell (1996) suggested that the Tafilalt deposit represents a trophically controlled assemblage, in which fish represented the primary food source for theropods. High theropod diversity might be explained by the presence of a large top predator, such as Carcharodontosaurus, which was able to take large prey that were otherwise unavailable to smaller theropods (cf. Rauhut, 1999). Diverse carnivores can coexist in the same environment, exploiting a paucispecific prey assemblage. A modern analogue is provided by African flamingo colonies, consisting of one or two prey species (Phoenicopterus ruber and Phoeniconaias minor), that are exploited by as many as nine predator species. These include falconiforms, larids, ciconiids, canids and hyaenids (Ogilvie and Ogilvie, 1986). Intraguild predation among carnivores can also increase predator diversity. It is well documented in extant carnivorans (Palomares and Caro, 1999). Intraguild predation may well have existed among theropods and could partly explain their diversity in paucispecific assemblages. Theropod abundance in an otherwise paucispecific assemblage may in some cases be due to an abundance of carrion. It is conceivable, for example that fish and 
pterosaur corpses were abundant on the Solnhofen and Santana shorelines after storm events.

A possibility worth considering is that theropods may be over-represented in marine or lagoonal deposits because their size, which was often small, and their pneumatic skeletons allowed their carcasses to float and drift for longer times than those of other dinosaurs. However, this hypothesis is contradicted by the presence in many marine deposits of non-theropod dinosaurs that outnumber theropods in the number of taxa represented (see below).

The fact that compsognathid theropods are found in both the Santana and Solnhofen Formations suggests that members of this group were specifically adapted to inhabit semi-arid environments. Compsognathids may have been ecologically similar to some varanid lizards, such as Varanus griseus (see Kirschner et al., 1996), in being opportunistic carnivores that also consumed some vegetation. The preservation of gut and stomach contents in some vertebrate fossils from the Santana Formation (Wilby and Martill, 1992) holds out the hope that this may be a testable hypothesis (cf. Munk and Sues, 1993).

\section{SYSTEMATICS}

\author{
DINOSAURIA Owen, 1842 \\ SAURISCHIA Seeley, 1887 \\ THEROPODA Marsh, 1881 \\ COELUROSAURIA Huene, 1914 \\ COMPSOGNATHIDAE Cope, 1875
}

Genus Mirischia gen. nov.

Type species: Mirischia asymmetrica gen. et sp. nov. (Text-figures 1-9)

Derivation of name: Mirischia, Mir, Latin, wonderful; Ischia, Greek, pertaining to the pelvis (and not the ischia alone).

Holotype: SMNK 2349 PAL

Locality: Region of Araripina (exact locality unknown), Chapada do Araripe, Pernambuco, northeastern Brazil.
Horizon and age: Romualdo Member of the Santana Formation, Araripe Group. Lower Cretaceous (Martill and Wilby, 1993). A ?late Albian age is inferred by Pons et al. (1990).

Material: The holotype is the only known specimen. Prior to preparation, one dorsal vertebral centrum with part of the neural arch, four sacral vertebral centra with parts of neural arches, several gastralia and lithified contents of the terminal part of the intestinal tract, an articulated pelvis and proximal parts of the hind limbs including partial left and right ilia, left and right ossa pubis, slightly damaged left and right ischia, partial left and right femora, the proximal end of a right tibia, and the proximal end of a right fibula were contained in a single calcium carbonate concretion.

Diagnosis: Compsognathus-like compsognathid coelurosaur, probably reaching larger adult body size than other compsognathids, pubic peduncle of ilium with concave cranial surface, pubic boot with no cranial expansion and 32\% total length of pubis, pedicular fossae located craniodorsal to neural canal on caudal dorsal vertebra, distal tips of the neural spines between $63 \%$ and $67 \%$ longer than their bases, ventral surface of sacral centra bearing shallow median depressions at either end, and extremely thin bone walls to all known elements. For a complete description see Martill et al. (2000).

\section{BRIEF ANATOMICAL DESCRIPTION}

\section{Vertebral Column}

Five articulated vertebrae are known for Mirischia, including a partial dorsal, a dorsosacral, and three sacrals, the most caudal of which is incomplete (Figs. 1-3). The vertebrae all retain distinct neurocentral sutures. Most of the cranial half of the dorsal vertebrae is missing; on its right side, a short rib in articulation with its transverse process is preserved. Pedicular fossae are located dorsal to

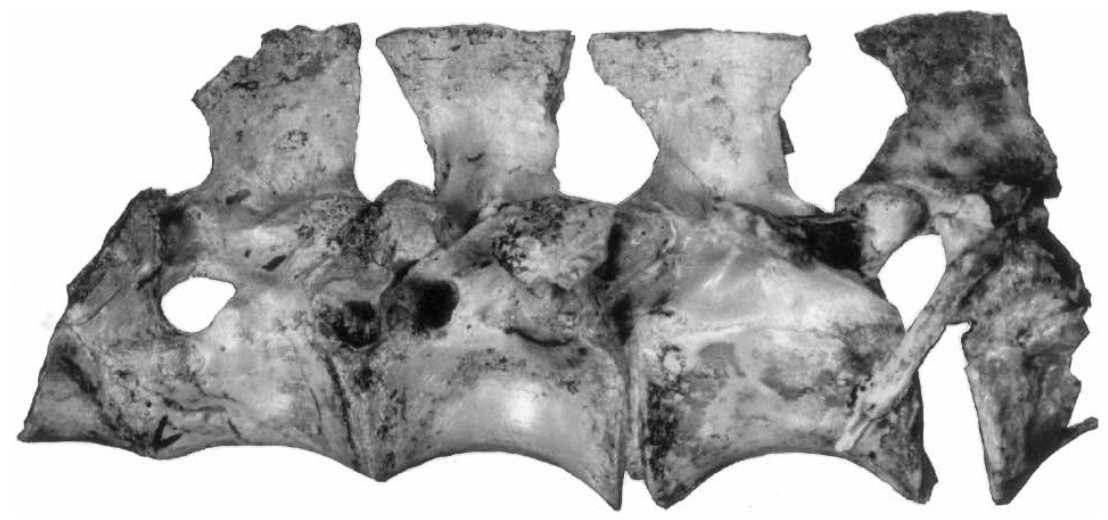

FIGURE 1 Preserved dorsal, dorsosacral and cranial sacral vertebrae of Mirischia asymmetrica in right lateral view. Magnification $\times 3$. 


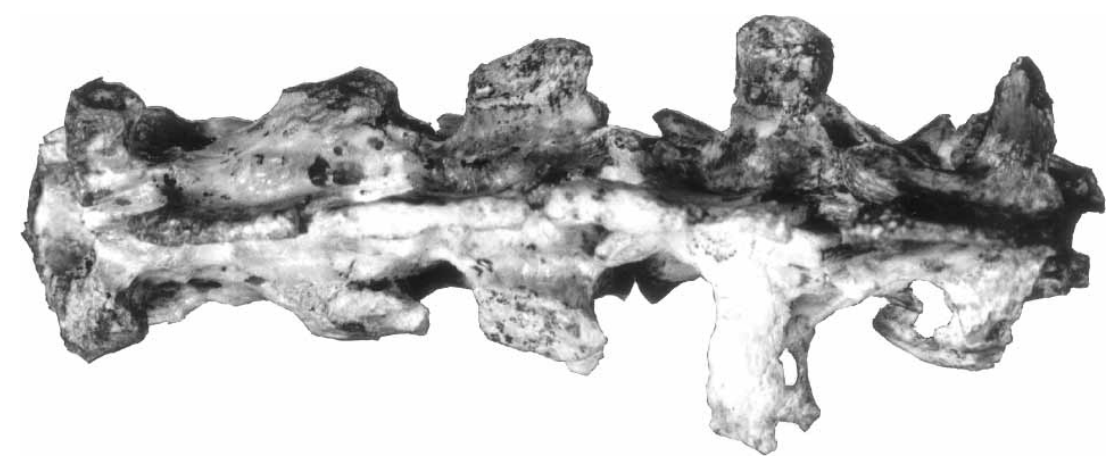

FIGURE 2 Preserved dorsal, dorsosacral and cranial sacral vertebrae of Mirischia asymmetrica in dorsal view. Magnification $\times 3$.

the neural canal on the cranial surface of this vertebra (Fig. 3). That on the left is a foramen linked to the pneumatic interior of the neural arch while that on the right is a fossa. The intervertebral articulation between the second and third vertebrae remains unfused, hence the identification of the second as a dorsosacral (Martill et al., 2000). The sacral vertebrae are fused and belong to the cranial part of the sacrum, the total length of which is unknown.

The sacral vertebrae of Mirischia are amphicoelous. On the ventral surface of each there are both parallel striations that run the length of the centrum and shallow depressions located cranially and caudally along the midline. On the second sacral vertebra, the caudal depression continues onto the ventral surface of the third centrum. To our knowledge, such depressions have not been reported in any other theropod. The more extensive ventral sulcus seen on

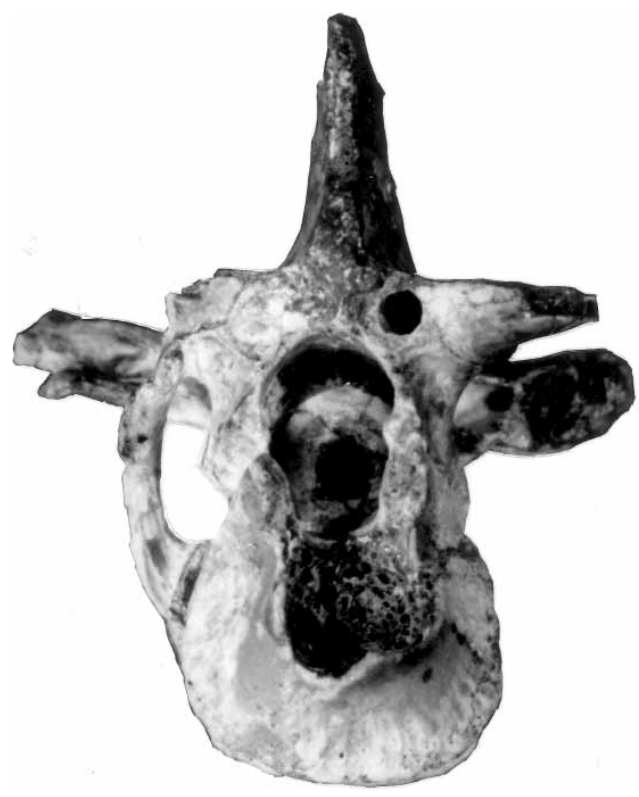

FIGURE 3 Preserved vertebrae of Mirischia asymmetrica in cranial view. Note the pedicular fossae dorsolateral to the neural canal. Magnification $\times 3.4$. the sacral vertebrae of eumaniraptoran coelurosaurs is clearly different.

The neural spines of Mirischia are cranially and caudally concave, such that the apex of the spine is between $63 \%$ and $67 \%$ longer than the base (Fig. 1).

\section{Pelvis}

The pelvis is nearly complete, with both ossa pubis, both ischia and parts of both ilia present. The distal ends of the ischia are missing, as are the caudal-most portions of both ilia. The right ilium is better preserved than the left. The width of the pelvis shows that Mirischia had a very narrow body, being approximately $30 \mathrm{~mm}$ wide across the sacrum. The preacetabular process of the ilium terminates in a square-ended process that is directed cranioventrally. The ventromedial part of this process is slightly angled laterally with respect to the dorsomedial part (Fig. 4). The ventral surface of the pubic peduncle is convex craniocaudally, with a shallow longitudinal groove; the peduncle is directed cranioventrally and it has a concave cranial margin. A cranially concave pubic peduncle also occurs in the Tyrannosauroidea. However, since there is no indication that Mirischia is a member of that clade, we here regard this character as a diagnostic feature of Mirischia. The pubis forms a long $(145 \mathrm{~mm})$ and slender shaft, the distal end of which forms a large pubic boot (Figs. 5 and 6). The length of this boot $(53 \mathrm{~mm})$ extends $37 \%$ of the length of the pubic shaft. Proximocaudally, the pubis bears a caudally projecting rectangular flange. The angle between the long axis of the sacrum and the pubis is approximately $55^{\circ}$.

Mirischia is remarkable in that it has an obturator foramen on the caudally projecting rectangular flange of the right pubis, but a ventrally open notch in the corresponding position on the left pubis (Martill et al., 2000). Conjoined medial laminae of both ossa pubis together form a transverse pubic apron that extends from the proximal third of the pubis to the pubic boot (Fig. 7). An elongate pubic 


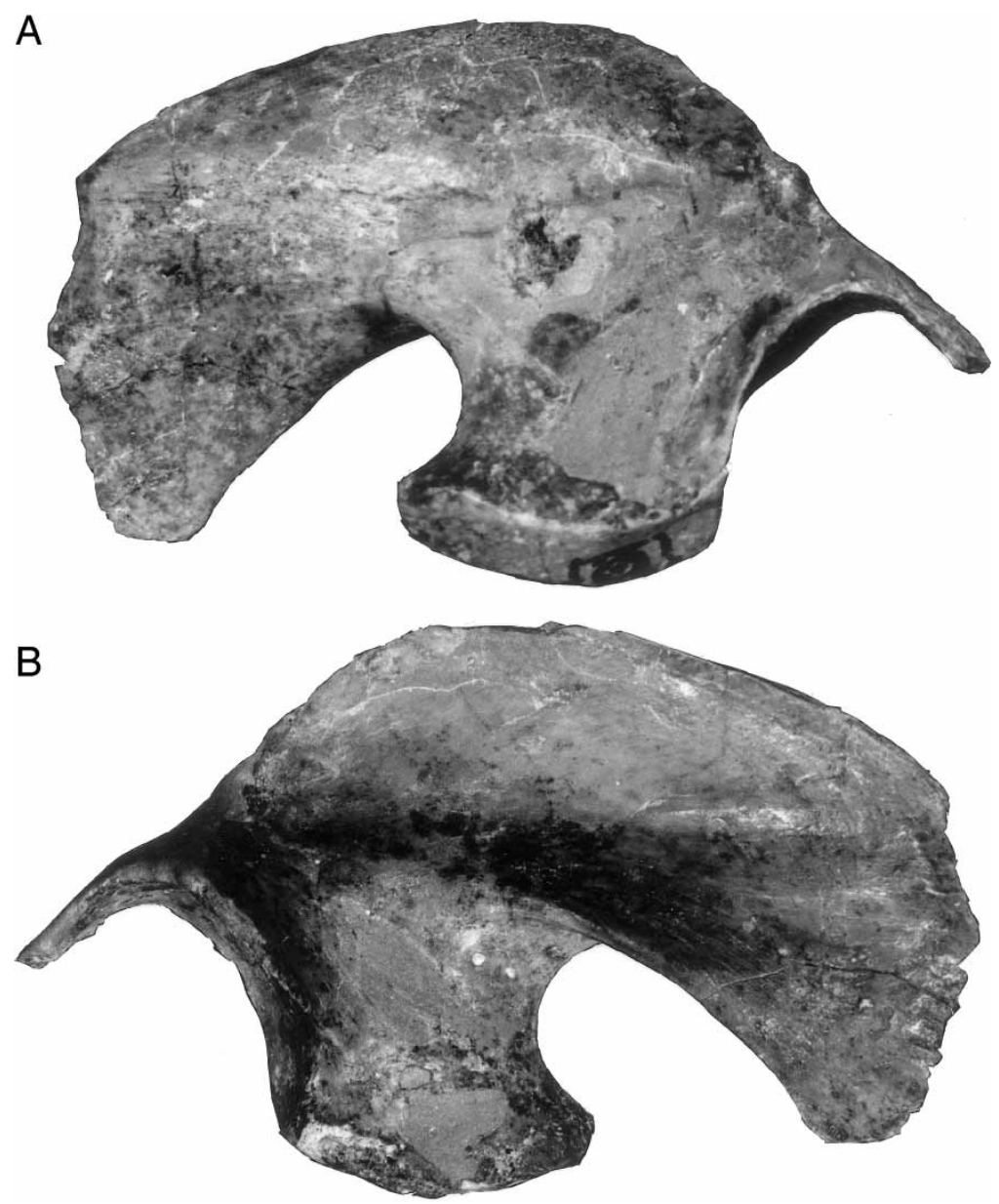

FIGURE 4 Preserved fragment of right ilium of Mirischia asymmetrica in medial (A, above) and lateral (B, below) views. Magnification $\times 1.5$.

foramen is present distally and divides the cranial third of the boot. As noted by Hutchinson (2001a), Martill et al. (2000) proposed that this foramen may have accommodated a ventral pneumatic duct, leading to a post-pubic air sac (Fig. 8).

The ischia of Mirischia are asymmetrical, that on the left being perforated by an oval foramen while that on the right has an open notch in the same position. The obturator flange on the right side is similar in shape to those of Sinosauropteryx prima (Currie and Chen, 2001) and Allosaurus fragilis (Pérez-Moreno et al., 1999). The caudal margin of the ischium in Mirischia is evenly concave. The angle between the pubis and ischium is approximately $60^{\circ}$ (Figs. 5 and 6).

\section{Femur}

The femur of Mirischia exhibits a craniodorsally curved shaft, a medially directed head set off at a right angle to the shaft, and a bifid, craniodorsally directed trochanter that is well separated from and distal to the head (Fig. 9). Most of the distal condyles are missing. Although the bifid trochanter was identified by Martill et al. (2000) as the lesser (or anterior) trochanter, it probably represents a fused accessory and lesser trochanter (Hutchinson, 2001b). Two small convexities caudolateral to the lesser trochanter were interpreted by Martill et al. (2000) as the insertion points of $m$. obturatorius and m. iliotrochantericus. Hutchinson (2001b) has suggested that this area represents a reduced trochanteric shelf and the attachment area for $m$. iliofemoralis externus. The fourth trochanter in Mirischia is a low ridge, located within the proximal third of the caudal surface of the femur.

\section{Tibia}

The right tibia is represented only by its proximal end. A shallow sulcus separates the cranial surface of the lateral condyle from the proximal third of the cnemial crest. The proximal condyles differ in shape, as is typical for theropods; the medial condyle is craniocaudally longer and mediolaterally wider than the lateral condyle. The two condyles are separated by a shallow flexor fossa. Only the proximal part of the fibular crest is preserved. 


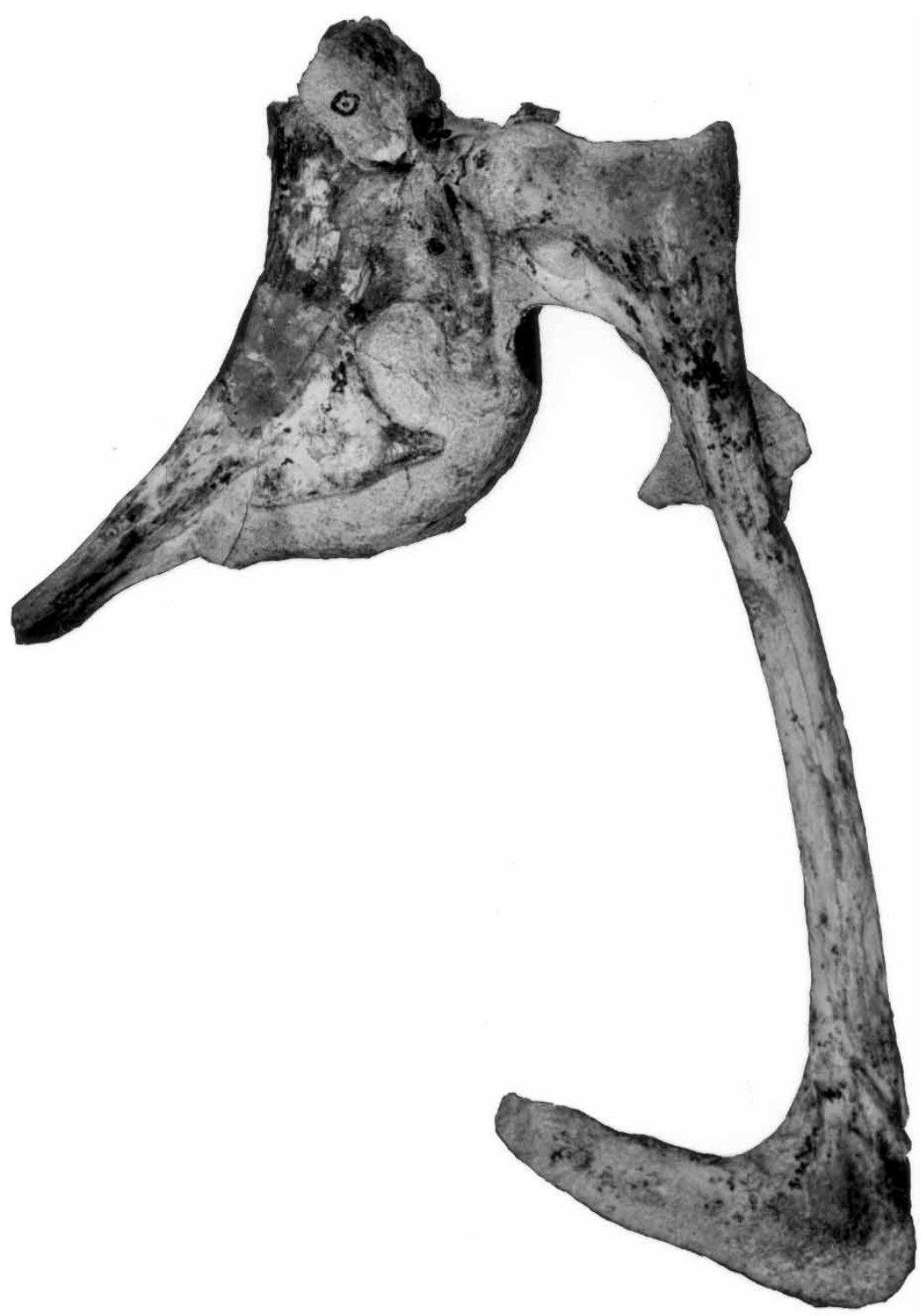

FIGURE 5 Pubis and ischium of Mirischia asymmetrica in right lateral view. Note enclosed foramen on proximal pubis and ventrally open obturator notch on ischium. Magnification $\times$ 1.2.

In distal cross-section, the shaft of the tibia is subtriangular.

\section{Fibula}

The right fibula is also represented only by a proximal fragment. On its medial surface, this bears a deep, parallel-sided sulcus. This is separated by a raised area from a more caudally situated depression (Fig. 10).

\section{COMPARISONS}

Mirischia closely resembles compsognathid theropods from the Late Jurassic of Europe (Compsognathus longipes) and the Early Cretaceous of Europe (Aristosuchus pusillus) and China (Sinosauropteryx prima) (Bidar et al., 1972; Ostrom, 1978; Chen et al., 1998; Naish et al., 2001; Currie and Chen, 2001). However, it has proven difficult to find convincing derived characters that unite compsognathids, setting them apart from all other theropods. Currie and Chen (2001) suggested the presence of a proportionally large skull, unserrated premaxillary but serrated maxillary teeth, slender cervical ribs, short forelimbs, limited cranial expansion of the pubic boot, a prominent ischial obturator process, fan-shaped dorsal neural spines, a prominent ulnar olecranon process and a powerful manual phalanx I-1 as characters indicating a monophyletic Compsognathidae. However, they noted that some of these characters are widely distributed within Theropoda. Pending further study we provisionally accept compsognathid monophyly, regarding neural spines on the dorsal vertebrae that are craniocaudally 


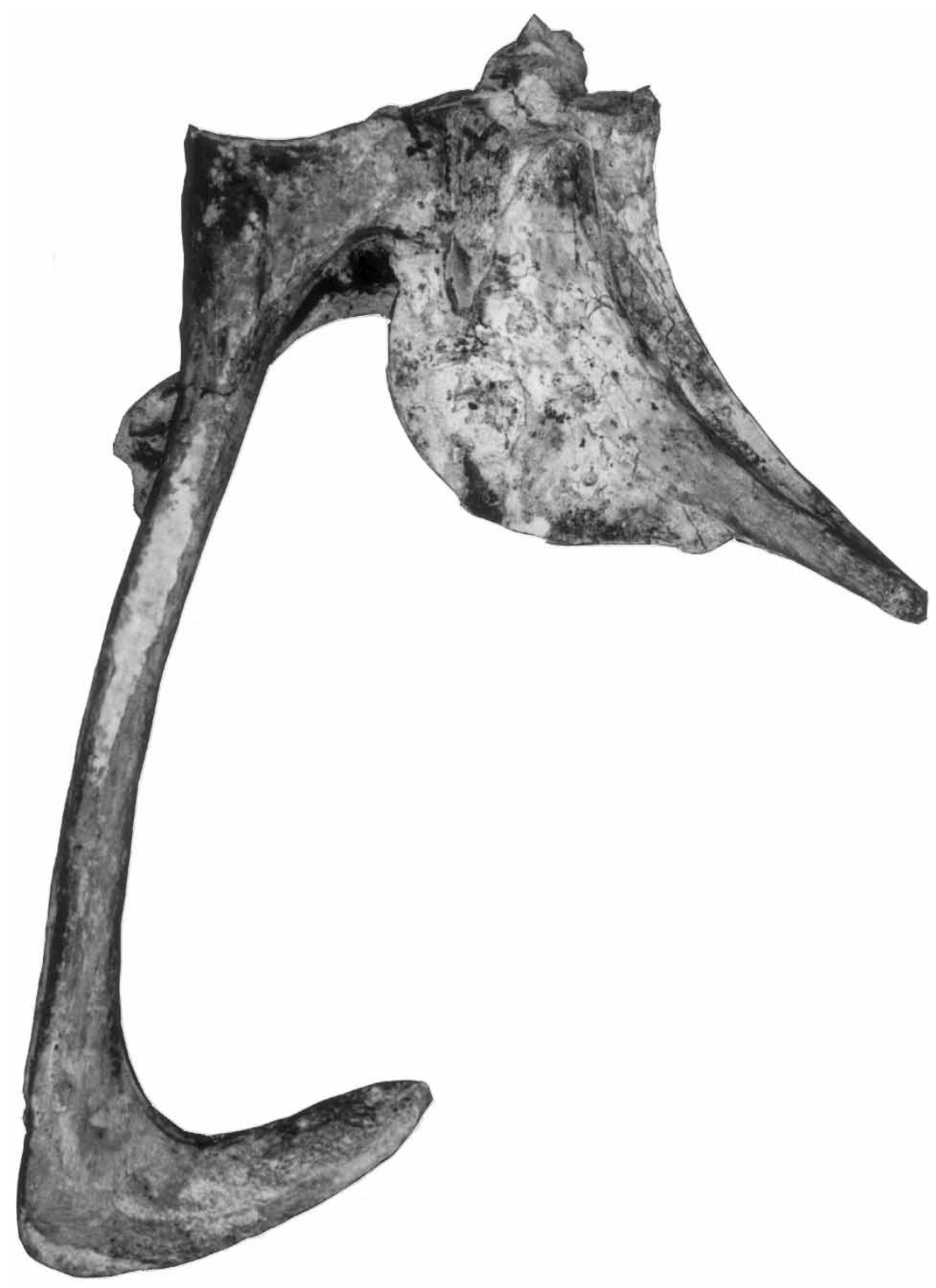

FIGURE 6 Pubis and ischium of Mirischia asymmetrica in left lateral view. Note the absence of the enclosed foramen present on the right pubis and the enclosed obturator foramen on the ischium. Magnification $\times 1.2$.

longer at the dorsal apex than at the base ("fanshaped" of Chen et al., 1998) and limited cranial expansion of the pubic boot (Martill et al., 2000; Naish et al., 2001) as diagnostic features indicating membership of this group (Fig. 11).

Like Sinosauropteryx, Mirischia exhibits "fanshaped" neural spines. This character is also seen in the dorsal neural spines of ornithomimosaurs, where the spine may be 55\% longer at its tip than at its base (Makovicky, 1995). It is also reported in a basal troodontid, Sinovenator changii (Xu et al., 2002). The distal expansion of the neural spines appears greater in Mirischia than in other compsognathids and ornithomimosaurs. The neural spines of Mirischia are between $63 \%$ and $67 \%$ longer at their distal tips than at their bases. Since compsognathids, ornithomimosaurs and troodontids are almost certainly not close relatives (Holtz, 2000; Xu et al., 2002), it appears likely that any feature which is held in common among these groups represents convergence. Distal expansion of the neural spine therefore stands as a possible compsognathid character. However, we note that ossification of the dorsal tip and of the cranial and caudal surfaces of the neural spine may vary during ontogeny. "Fan-shaped" neural spines may yet prove to be more widespread among theropods than has so far been recognized.

A prominent pubic boot with only moderate cranial expansion is present in Mirischia, Compsognathus, Sinosauropteryx and Aristosuchus. This could also be a derived compsognathid character. However, similar boot morphologies occur in other coelurosaurs (Currie and Chen, 2001), and it is difficult to quantify this character. We here compare 


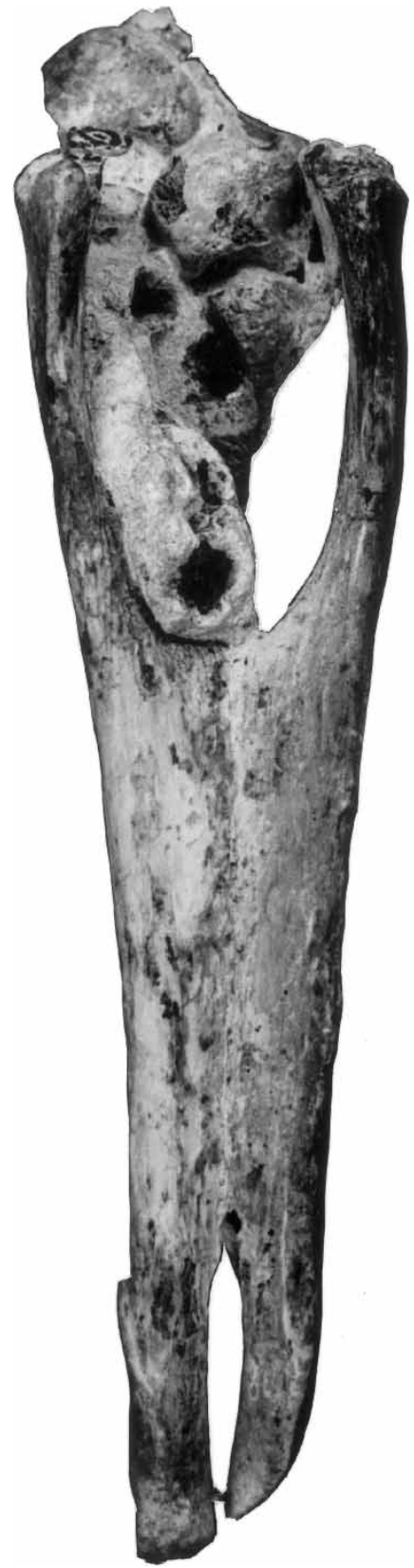

FIGURE 7 Conjoined ossa pubis of Mirischia asymmetrica in cranial view with intestinal infill preserved between the pubes. Magnification $\times 2.4$.

Mirischia directly with the other compsognathid taxa and with the contemporaneous coelurosaur Santanaraptor (Kellner, 1999).

\section{Sinosauropteryx prima}

The holotype of Sinosauropteryx prima and at least one of the referred specimens (NIGP 127587) exhibit the same derived forelimb characters, including the proximomedial flange on the first metacarpal (Currie and Chen, 2001). Hence, we provisionally regard NIGP 127587 as a representative of S. prima. A third

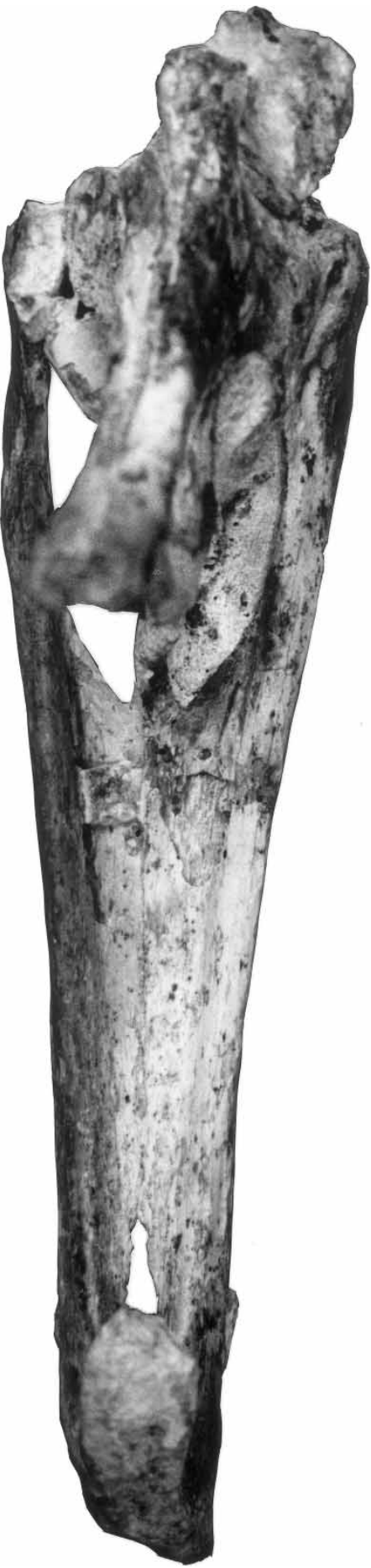

FIGURE 8 Conjoined ossa pubis and ischia of Mirischia asymmetrica in caudal view. Magnification $\times 2.4$.

specimen (GMV 2124) differs from the type specimen and from NIGP 127587 in its skeletal proportions and other anatomical features. On the basis of a cladistic analysis, Longrich (2000) concluded that the type specimen and GMV 2124 might represent two unrelated taxa.

In S. prima, the preacetabular process of the ilium has near-parallel dorsal and ventral margins; it does 


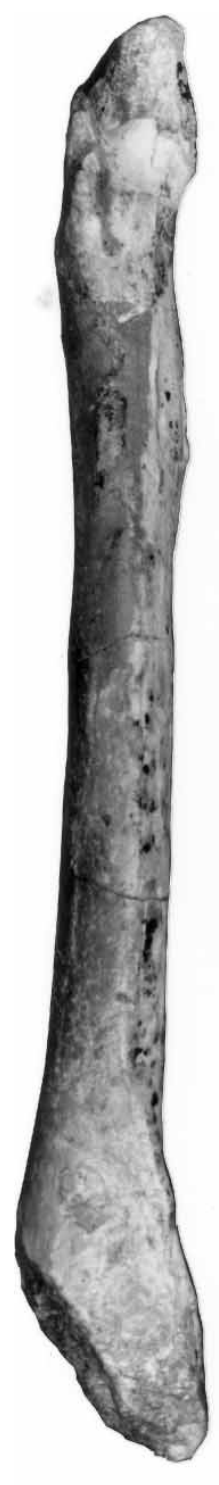

A

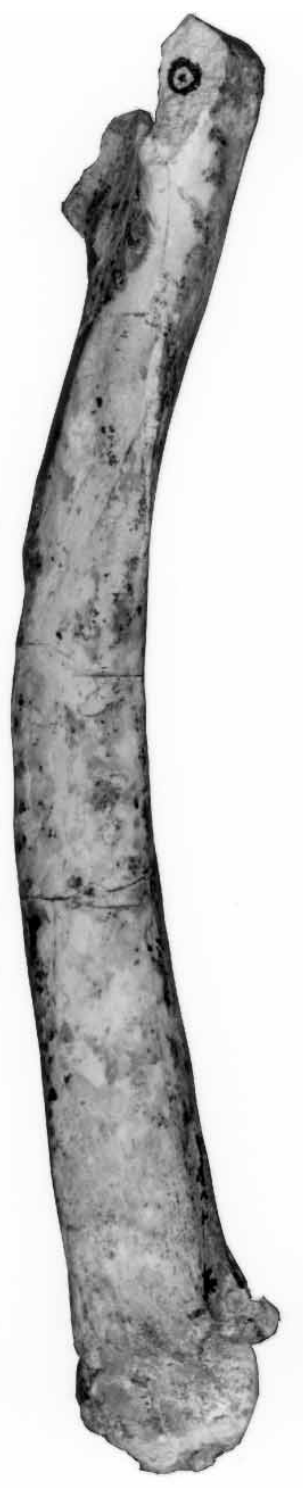

B

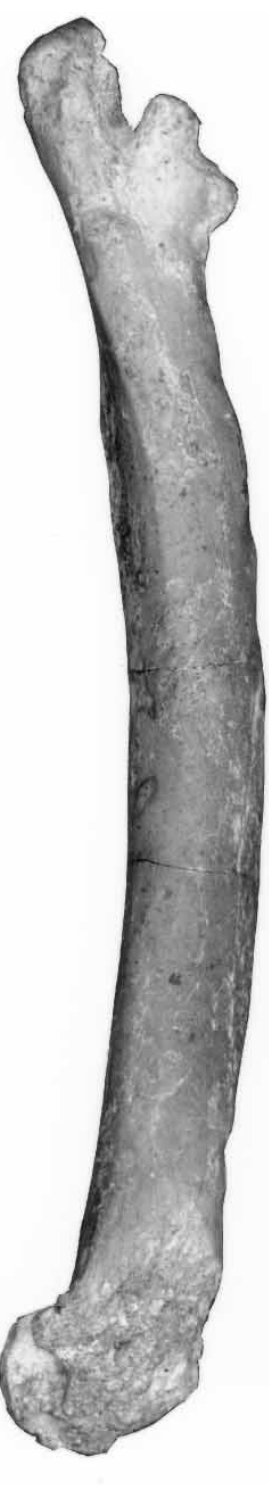

C

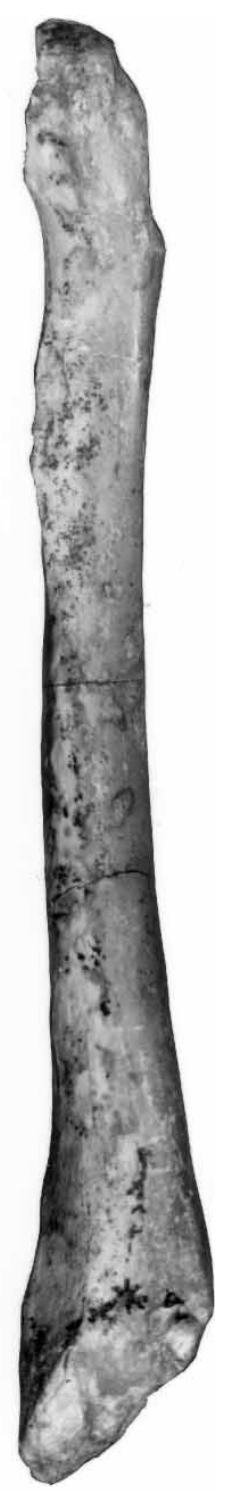

D

FIGURE 9 Right femur of Mirischia asymmetrica in A, cranial; B, medial; C, lateral; and D, caudal views. The caput is absent in these figures. Magnification $\times 1.1$.

not exhibit marked ventral curvature at its cranial tip. In contrast, in Mirischia the preacetabular process curves ventrally, exhibiting a notably convex dorsal margin and a concave ventral margin. While S. prima has distally expanded neural spines on its dorsal vertebrae, these are not as expanded as those of Mirischia (Chen et al., 1998). The pubic boot in S. prima is proportionally smaller (approximately $27 \%$ of total pubis length) than that of Mirischia, but the two taxa are similar in the morphology of their femora, tibiae and ischia. In S. prima, the lesser trochanter appears similar in form and size to that of Mirischia, although a distinct accessory trochanter is not evident in S. prima (Chen et al., 1998; Currie and Chen, 2001). While in Mirischia and Compsognathus the angle between the long axis of the sacrum and the pubis is approximately $55^{\circ}$, this angle is larger (about $75^{\circ}$ ) in S. prima, where the pubis is more vertical. This character is obviously correlated with the inclination of the pubic peduncle.

\section{Aristosuchus pusillus}

The holotype of Aristosuchus, long confused with Calamospondylus oweni (see Naish et al., 2001; Naish, 2002), more resembles Compsognathus in the form of its pubis than any other theropod, so it is regarded as an ostensible compsognathid. The concavities and parallel striations present on the ventral surfaces of the sacral vertebrae in Mirischia are not present in Aristosuchus. The most cranial of the vertebrae in Aristosuchus also lacks the pedicular 


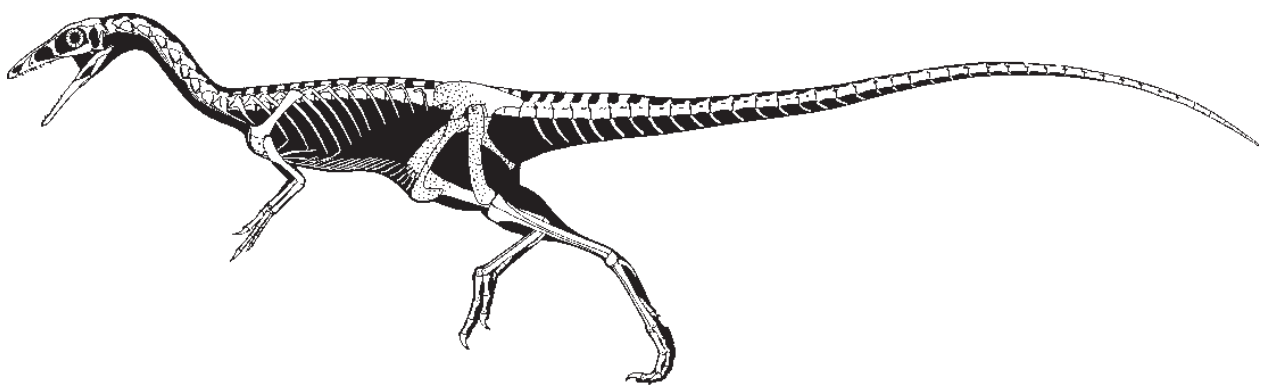

FIGURE 10 Skeletal reconstruction of the compsognathid Compsognathus with known elements of Mirischia asymmetrica stippled. Diagram by kind courtesy of Gregory S. Paul.

fossae seen on the cranial surface of the dorsal vertebra of Mirischia.

Two elements provisionally referred to Aristosuchus are strikingly similar to corresponding elements in Mirischia. Galton (1973) described a fragmentary proximal femur from the Wessex Formation of the Isle of Wight (specimen BMNH R5194), referring it to Aristosuchus (see Naish et al., 2001). Like the femur of Mirischia, BMNH R5194 has fused lesser and accessory trochanters that exhibit a shallow V-shaped notch at their point of fusion. This morphology is probably primitive for coelurosaurs, however, and not a shared derived similarity (Hutchinson, 2001b). The reduced fourth trochanter in BMNH R5194 indicates that it is from a coelurosaur, and its similarity to the femora of Mirischia further suggests that it belongs to a compsognathid (Naish et al., 2001). This inference is provisional in the absence of further material, however. If this specimen is from Aristosuchus, this taxon differs from Mirischia in having thicker bone walls. An isolated ischium that has provisionally been referred to Aristosuchus (Naish, 2002) resembles that of Mirischia, but differs from it in that the obturator process is triangular and thus more like the ischia of Compsognathus.

\section{Compsognathus longipes}

Mirischia closely resembles Compsognathus in having a pubic boot that lacks a cranial projection and that is almost flat ventrally. The pubic boot of Mirischia is virtually identical in shape to that of the Nice specimen of Compsognathus (Bidar et al., 1972). However, the pubic boot of Compsognathus is proportionally larger than that of Mirischia. In the Nice Compsognathus, the length of the pubic boot is approximately $41 \%$ the total length of the shaft of the pubis (Bidar et al., 1972) while in the German specimen (based on the cast BMNH R49159) it is approximately $45 \%$. In Mirischia, the boot represents $32 \%$ of the total length of the pubis. There appear to be other differences between Compsognathus and Mirischia, including a triangular ischial obturator process in Compsognathus. However, these are difficult to validate because of poor or incomplete preservation of skeletal material (Bidar et al., 1972; Ostrom, 1978; personal observations).

\section{Santanaraptor placidus}

Mirischia is not synonymous with Santanaraptor. As pointed out above, Santanaraptor has a proportionally larger ischial obturator notch that fully separates the pubic peduncle from the obturator process (Kellner, 1999). In Santanaraptor the femur bears a large sulcus that is not present in Mirischia.

\section{DISCUSSION: THE SANTANA DINOSAUR FAUNA}

Referral of Mirischia to Compsognathidae has implications for the palaeobiogeographic affinities of the Santana dinosaur fauna. All previously known compsognathids are from Eurasia (Bidar et al., 1972; Ostrom, 1978; Ji and Ji, 1997; Zinke, 1998; Chen et al.,

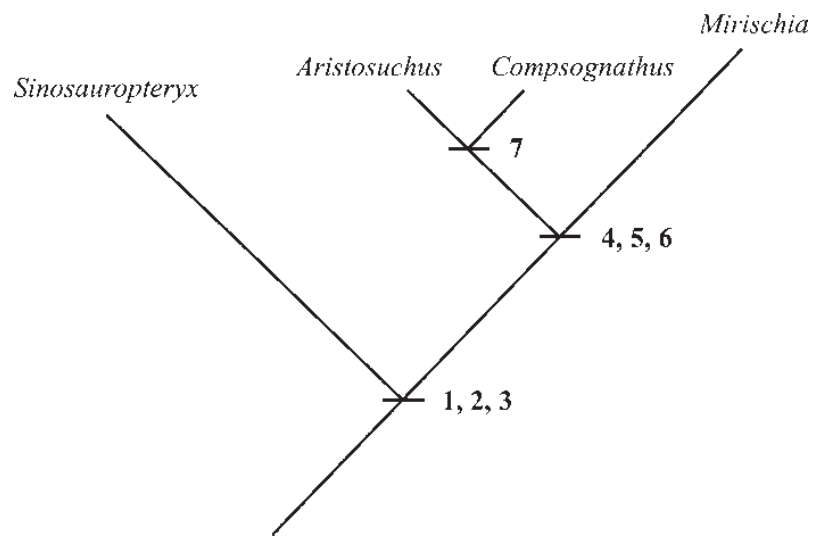

FIGURE 11 Tentative proposal of phylogenetic relationships of compsognathid taxa with compsognathid monophyly and choice of outgroups based on previous studies (Holtz, 1994; 2000). Characters defining relationships in the cladogram are as follows: (1) Unserrated premaxillary teeth; (2) Reduced/absent cranial process on pubic boot; (3) "Fan-shaped" dorsal neural spines; (4) Proportionally large pubic boot $(<32 \%$ total pubis length); (5) Dorsal/sacral neural spines proportionally longer than those of Sinosauropteryx; (6) Angle between long axis of sacrum and shaft of pubis about $55^{\circ}$; (7) Triangular obturator process. 
1998; Rauhut, 2000; Naish et al., 2001; Currie and Chen, 2001). If compsognathids first evolved as an endemic Laurasian group, Mirischia constitutes evidence of an interchange of dinosaurs between Europe and South America, probably via Africa, during the Early Cretaceous. Alternatively, the geographic distribution of compsognathids may reflect vicariance following the fragmentation of Pangaea.

The referral of a theropod sacrum from the Santana Formation to Oviraptorosauria by Frey and Martill (1995) is also biogeographically significant, if this assignment proves to be correct. Thus far, there are only two other reports of members of Oviraptorosauria from Gondwana: a surangular and a dorsal vertebra from the Early Cretaceous of Australia (Currie et al., 1996), and an isolated cervical vertebra from the Late Cretaceous of Argentina (Frankfurt and Chiappe, 1999).

The spinosauroid Irritator challengeri (Martill et al., 1996) indicates that the dinosaur fauna of the Santana Formation includes elements at the suprageneric level that also are found in the Early and mid-Cretaceous of Africa. Other similarities between the Santana tetrapod assemblage and North African Cretaceous assemblages are well known (Buffetaut and Taquet, 1979; but see Kellner, 1994; Ortega et al., 2000), suggesting that Eurasian dinosaurs could have spread to South America by way of Africa.

As noted above, Kellner (1999) suggested that Santanaraptor may belong to Maniraptoriformes. This coelurosaur clade is now well documented in the Cretaceous of South America, where it is represented by Unenlagia, oviraptorosaurs, alvarezsaurids and avialians (Novas, 1996; 1997; Novas and Puerta, 1997; Frankfurt and Chiappe, 1999). Maniraptoriform dinosaurs were evidently widely distributed; they appear to have had an almost global geographic range in the Cretaceous.

In conclusion, the presence in the Santana Formation of spinosauroids, compsognathids and maniraptoriforms casts further doubt on suggestions (Bonaparte, 1996) that Gondwana had a distinct, endemic tetrapod fauna during the Cretaceous.

\section{Acknowledgements}

We thank Marie-Celine Buchy and an anonymous referee for critical reading of the manuscript and Oliver Rauhut, Nick Longrich and Hans-Dieter Sues for discussion. Ben Creisler provided assistance with the name of the new taxon. Greg Paul kindly allowed use of his updated Compsognathus reconstruction. Thanks to Sandra Chapman (Natural History Museum, London) for allowing us to examine material in her care. DMM was supported by a University of Portsmouth Fellowship. Special thanks to Dr Paulo Brito (Rio) and Dr Artur Andrade (Crato) for their invaluable help in Brazil.

\section{References}

Barthel, K.W., Swinburne, N.H.M. and Conway Morris, S. (1990). Solnhofen: A Study in Mesozoic Palaeontology. Cambridge University Press, Cambridge.

Bidar, A., Demay, L. and Thomel, G. (1972). Compsognathus corallestris, nouvelle espèce de dinosaurien theropode $\mathrm{du}$ Portlandien de Canjuers (sud-est de la France). Annales $d u$ Muséum d'Histoire Naturelle de Nice 7, 9-40.

Bonaparte, J.F. (1996). Cretaceous tetrapods of Argentina. Münchner Geowissenschaften, Abhandlungen 30, 73-130.

Buffetaut, E. and Suteethorn, V. (1999). The dinosaur fauna of the Sao Khua Formation of Thailand and the beginning of the Cretaceous radiation of dinosaurs in Asia. Palaeogeography, Palaeoclimatology, Palaeoecology 150, 13-23.

Buffetaut, E. and Taquet, P. (1979). An early Cretaceous terrestrial crocodilian and the opening of the South Atlantic. Nature 280, $486-487$.

Campos, D. de A. (1985). Occurrencia de uma novo arcosauro na Chapada do Araripe. Annais Academia brasiliera Cincia 57, 140-141.

Campos, D. de A. and Kellner, A.W.A. (1991). Dinosaurs of the Santana Formation. In Maisey, J.G. (ed), Santana Fossils, an Illustrated Atlas, pp. 372-375. TFH Publications, Neptune, New Jersey.

Charig, A.J. and Milner, A.C. (1997). Baryonyx walkeri, a fish-eating dinosaur from the Wealden of Surrey. Bulletin of the Natural History Museum, London (Geology) 53, 11-70.

Chen, P.-J., Dong, Z.-M. and Zhen, S.-N. (1998). An exceptionally well-preserved theropod dinosaur from the Yixian Formation of China. Nature 391, 147-152.

Crane, P. and Maisey, J.G. (1990). Fossil plants. In Maisey, J.G. (ed), Santana Fossils, an Illustrated Atlas, pp. 414-419. TFH Publications, Neptune, New Jersey.

Currie, P.J. and Chen, P.-J. (2001). Anatomy of Sinosauropteryx prima from Liaoning, northeastern China. Canadian Journal of Earth Sciences 38, 1705-1727.

Currie, P.J. and Russell, D.A. (1988). Osteology and relationships of Chirostenotes pergracilis (Saurischia, Theropoda) from the Judith River (Oldman) Formation of Alberta, Canada. Canadian Journal of Earth Sciences 25, 972-986.

Currie, P.J., Vickers-Rich, P. and Rich, T.H. (1996). Possible oviraptorosaur (Theropoda, Dinosauria) specimens from the Early Cretaceous Otway Group of Dinosaur Cove, Australia. Alcheringa 20, 73-79.

Elzanowski, A. (2001). A new genus and species for the largest specimen of Archaeopteryx. Acta Palaeontologica Polonica 46, 519-532.

Frey, E. and Martill, D.M. (1995). A possible oviraptosaurid theropod from the Santana Formation (Lower Cretaceous, Albian) of Brazil. Neues Jahrbuch für Geologie und Paläontologie, Monatshefte 1995, 397-412.

Frankfurt, N.G. and Chiappe, L.M. (1999). A possible oviraptorosaur from the Late Cretaceous of northwestern Argentina. Journal of Vertebrate Paleontology 19, 101-105.

Gaffney, E. and Meylan, P.A. (1991). Primitive pelomedusid turtle. In Maisey, J.G. (ed), Santana Fossils, an Illustrated Atlas, pp. 326-339. TFH Publications, Neptune, New Jersey.

Galton, P.M. (1973). A femur of a small theropod dinosaur from the Lower Cretaceous of England. Journal of Paleontology 47, 996-1001.

Hirayama, R. (1998). Oldest known sea turtle. Nature 392, 705-707.

Holtz, T.R. (1994). The phylogenetic position of the Tyrannosauridae: implications for theropod systematics. Journal of Paleontology 68, 1100-1117.

Holtz, T.R. (1998). Spinosaurs as crocodile mimics. Science 282, $1276-1277$

Holtz, T.R. (2000). A new phylogeny of the carnivorous dinosaurs. Gaia 15, 5-61.

Hutchinson, J.R. (2001a). The evolution of pelvic osteology and soft tissues on the line to extant birds (Neornithes). Zoological Journal of the Linnean Society 131, 123-168. 
Hutchinson, J.R. (2001b). The evolution of femoral osteology and soft tissues on the line to extant birds (Neornithes). Zoological Journal of the Linnean Society 131, 169-197.

Hwang, S.H., Norell, M.A., Ji, Q. and Gao, K. (2004). A large compsognathid from the Early Cretaceous Yixian Formation of China. Jounal of Systematic Palaeontology 2, 13-30.

Ji, Q. and Ji, S. (1997). Advance in Sinosauropteryx research. Chinese Geology 7, 30-32.

Kellner, A.W.A. (1994). Comments on the palaeobiogeography of Cretaceous archosaurs during the opening of the South Atlantic Ocean. Acta Geologica Leopoldensia 17, 615-625.

Kellner, A.W.A. (1996a). Remarks on Brazilian dinosaurs. Memoirs of the Queensland Museum 39, 611-626.

Kellner, A.W.A. (1996b). Fossilized theropod soft tissues. Nature $379,32$.

Kellner, A.W.A. (1999). Short note on a new dinosaur (Theropoda, Coelurosauria) from the Santana Formation (Romualdo Member, Albian) northeastern Brazil. Boletim do Museu Nacional, Nova Serie, Rio de Janeiro, Brasil 49, 1-8.

Kellner, A.W.A. (2001). New information on the theropod dinosaurs from the Santana Formation (Aptian-Albian), Araripe Basin, northeastern Brazil. Journal of Vertebrate Paleontology 21(Suppl. 3), 67.

Kellner, A.W.A. and Campos, D. de A. (1996). First Early Cretaceous theropod dinosaur from Brazil. Neues Jahrbuch für Geologie und Paläontologie, Abhandlungen 199, 151-166.

Kellner, A.W.A. and Tomida, Y. (2000). Description of a new species of Anhangueridae (Pterodactyloidea) with comments on the pterosaur fauna from the Santana Formation (AptianAlbian), northeastern Brazil. National Science Museum Monographs, Tokyo 17, 1-135.

Kirschner, A., Muller, T. and Seufer, H. (1996). Faszination Warane, Plege und Zucht. Kirschner and Seufer-Verlag (Keltern-Weiler), Karlsruhe.

Krause, D.W., Rogers, R.R., Forster, C.A., Hartman, J.H., Buckley, G.A. and Sampson, S.D. (1999). The Late Cretaceous vertebrate fauna of Madagascar; implications for Gondwanan paleobiogeography. GSA Today 9(8), 1-7.

Leonardi, G. (1987). Pegadas de dinosauros (Carnosauria, Coelurosauria, Iguanodontidae) na Formação Piranhas da Bacia do Rio de Peixe, Sousa, Paraíba, Brasil. Anais do X Congresso Brasiliero de Paleontologia, 19th-25th July, Rio de Janeiro, Sociedade Brasileira de Paleontologia, 337-351.

Leonardi, G. and Borgamanero, G. (1981). Sobre uma possivel occorência de Ornithischia na formação Santana, Chapada do Araripe (Ceará). Revista Brasiliera Geociencia 11, 1-4.

Leonardi, G., Lima, C.V. and Oliveira Lima, F.H. (1987). Os dados numéricos relativos às pistas (e suas pegadas) das icnofaunas dinosaurianas do Cretáceo Inferior da Paraíba, e sua interpretação estatística; 1 -parâmetros das pistas. Anais do $X$ Congresso Brasiliero de Paleontologia, 19th-25th, July, Rio de Janeiro, Sociedade Brasileira de Paleontologia, 377-394.

Longrich, N. (2000). Origins and Evolution of the Trochanteric Crest and Semilunate Carpal of Maniraptoran Theropods. Unpublished M.Sc. Thesis, University of Chicago.

Maisey, J.G., ed. (1991). Santana Fossils, an Illustrated Atlas. TFH Publications, Neptune, New Jersey.

Makovicky, P.J. (1985). Phylogenetic Aspects of the Vertebral Morphology of Coelurosauria (Dinosauria: Theropoda). Unpublished M.Sc. Thesis, University of Copenhagen.

Makovicky, P.J. and Sues, H.-D. (1998). Anatomy and phylogenetic relationships of the theropod dinosaur Microvenator celer from the Lower Cretaceous of Montana. American Museum Novitates $3240,1-27$.

Marjanovic, D. (2000). Is Archaeopteryx really a bird? The Quarterly Journal of the Dinosaur Society 4(1), 15-19, 23.

Martill, D.M. (1988a). Preservation of fish in the Cretaceous of Brazil. Palaeontology 31, 1-18.

Martill, D.M. (1988b). A review of the terrestrial vertebrate fossils of the Oxford Clay (Callovian-Oxfordian) of England. Mercian Geologist 11, 171-190.

Martill, D.M. (1993). Fossils of the Santana and Crato Formations, Brazil. The Palaeontological Association, Field Guides to Fossils, London, Vol. 5.

Martill, D.M. and Unwin, D.M. (1989). Exceptionally well preserved pterosaur wing membrane from the Cretaceous of Brazil. Nature 340, 138-140.
Martill, D.M. and Wilby, P.R. (1993). Stratigraphy, Chapter 2. In Martill, D.M. (ed), Fossils of the Santana and Crato Formations, Brazil, pp. 20-50. The Palaeontological Association, Field Guides to Fossils, London, Vol. 5.

Martill, D.M., Cruickshank, A.R.I., Frey, E., Small, P.G. and Clarke, M. (1996). A new crested maniraptoran dinosaur from the Santana Formation (Lower Cretaceous) of Brazil. Journal of the Geological Society, London 153, 5-8.

Martill, D.M., Frey, E., Sues, H.-D. and Cruickshank, A.R.I. (2000). Skeletal remains of a small theropod dinosaur with associated soft structures from the Lower Cretaceous Santana Formation of northeastern Brazil. Canadian Journal of Earth Sciences 37, $891-900$.

Munk, W. and Sues, H.-D. (1993). Gut contents of Parasaurus (Pareiasauria) and Protorosaurus (Archosauromorpha) from the Kupferschiefer (Upper Permian) of Hessen, Germany. Paläontologische Zeitschrift 67, 169-176.

Naish, D. (2000). A small, unusual theropod (Dinosauria) femur from the Wealden Group (Lower Cretaceous) of the Isle of Wight, England. Neues Jahrbuch für Geologie und Paläontologie, Monatshafte 2000, 217-234.

Naish, D. (2002). The historical taxonomy of the Lower Cretaceous theropods (Dinosauria) Calamospondylus and Aristosuchus from the Isle of Wight. Proceedings of the Geologists' Association 113, 153-163.

Naish, D., Hutt, S. and Martill, D.M. (2001). Saurischian dinosaurs 2: Theropods. In Martill, D.M. and Naish, D. (eds), Dinosaurs of the Isle of Wight, pp. 242-309. The Palaeontological Association, Field Guides to Fossils, London, Vol. 10.

Novas, F.E. (1996). Alvarezsauridae, Cretaceous basal birds from Patagonia and Mongolia. Memoirs of the Queensland Museum $39,675-702$

Novas, F.E. (1997). Anatomy of Patagonylus puertai (Theropoda, Avialae, Alvarezsauridae), from the Late Cretaceous of Patagonia. Journal of Vertebrate Paleontology 17, 137-166.

Novas, F.E. and Puerta, P.F. (1997). New evidence concerning avian origins from the Late Cretaceous of Patagonia. Nature 387, 390-392.

Ogilvie, M. and Ogilvie, C. (1986). Flamingos. Alan Sutton, Gloucester.

Ortega, F., Gasparini, Z., Buscalioni, A.D. and Calvo, J.O. (2000). A new species of Araripesuchus (Crocodylomorpha, Mesoeucrocodylia) from the Lower Cretaceous of Patagonia (Argentina). Journal of Vertebrate Paleontology 20, 57-76.

Ostrom, J. (1978). The osteology of Compsognathus longipes Wagner. Zitteliana 4, 73-118, pls 7,8.

Padian, K., Hutchinson, J.R. and Holtz, T.R. (1999). Phylogenetic definitions and nomenclature of the major taxonomic categories of the carnivorous dinosaurs (Theropoda). Journal of Vertebrate Paleontology 19, 69-80.

Palomares, E. and Caro, T.M. (1999). Interspecific killing among mammalian carnivores. American Naturalist 153, 492-508.

Paul, G.S. (2001). Were the respiratory complexes of predatory dinosaurs like crocodilians or birds?. In Gauthier, J. and Gall, L.F. (eds), New Perspectives on the Origin and Early Evolution of Birds, Proceedings of the International Symposium in Honor of John H. Ostrom, pp. 463-482. Peabody Museum, Yale.

Pérez-Moreno, B.P., Chure, D.J., Pires, C., Marques da Silva, C., Dos Santos, V., Dantas, P., Póvoas, L., Cachão, M., Sanz, J.L. and Galopim de Carvalho, A.M. (1999). On the presence of Allosaurus fragilis (Theropoda: Carnosauria) in the Upper Jurassic of Portugal: first evidence of an intercontinental dinosaur species. Journal of the Geological Society, London 156, $449-452$.

Pons, D., Berthou, P.-Y. and Campos, D. de A. (1990). Quelques observations sur la palynologie de l'Aptien supérieur et de l'Albien du Bassin d' Araripe. In Campos, D. de A., Viana, M.S.S., Brito, P.M. and Beurlen, G. (eds), Atas do simposio sobre a Bacia do Araripe e Bacias Interiores do Nordeste, Crato, 14-16 de Junho de 1990., Crato, pp 241-252.

Rauhut, O.W.M. (1999). A dinosaur fauna from the Late Cretaceous (Cenomanian) of northern Sudan. Palaeontologia Africana 35, 61-84.

Rauhut, O.W.M. (2000). The dinosaur fauna from the Guimarota mine. In Martin, T. and Krebs, B. (eds), Guimarota-A Jurassic Ecosystem, pp. 75-82. Dr. Friedrich Pfeil, München. 
Rauhut, O.W.M. (2003). The interrelationships and evolution of basal theropod dinosaurs. Special Papers in Palaeontology 69, $1-213$.

Russell, D.A. (1996). Isolated dinosaur bones from the Middle Cretaceous of the Tafilalt, Morocco. Bulletin du Muséum national d'Histoire naturelle, Paris 18, 349-402.

Sampson, S.D., Witmer, L.M., Forster, C.A., Krause, D.W., O'Conner, P.M., Dodson, P. and Ravoavy, F. (1998). Predatory dinosaur remains from Madagascar: implications for the Cretaceous biogeography of Gondwana. Science 280, 1048-1051.

Sereno, P.C. (1999). The evolution of dinosaurs. Science 284, 2137-2147.

Sereno, P.C., Beck, A.L., Dutheil, D.B., Gado, B., Larsson, H.C.E., Lyon, G.H., Marcot, J.D., Rauhut, O.W.M., Sadleir, R.W., Sidor, C.A., Varricchio, D.D., Wilson, G.P. and Wilson, J.A. (1998). A long-snouted predatory dinosaur from Africa and the evolution of spinsaurids. Science 282, 1298-1302.

Sues, H.-D. (1994). On Chirostenotes, a Late Cretaceous oviraptorosaur (Dinosauria: Theropoda) from western North America. Journal of Vertebrate Paleontology 17, 698-716.

Sues, H.-D., Frey, E., Martill, D.M. and Scott, D.M. (2002). Irritator challangeri, a spinosaurid (Dinosauria: Theropoda) from the Lower Cretaceous of Brazil. Journal of Vertebrate Paleontology 22, 535-547.

Viohl, G. (1999). Fund eines neuen kleinen Theropoden. Archaeopteryx 17, 15-19.

Wilby, P.R. and Martill, D.M. (1992). Fossil fish stomachs: a microenvironment for exceptional preservation. Historical Biology 6, 25-36.

Xu, X., Norell, M.A., Wang, X.-L., Makovicky, P.J. and Wu, X.-C. (2002). A basal troodontid from the Early Cretaceous of China. Nature 415, 780-784.

Zinke, J. (1998). Small theropod teeth from the Upper Jurassic coal mine of Guimarota (Portugal). Pälaontologische Zeitschrift 72, 179-189.

\section{APPENDIX: A COMMENT ON SMALL DATA SETS}

The tetrapod assemblage of the Santana Formation is similar to that of the Jurassic Solnhofen Limestone, at least in terms of the reconstructed terrestrial palaeoenvironment and the presence of carnivorous terrestrial tetrapods. The hinterland of the Solnhofen lagoons, like that of the Santana lagoon, is thought to have been semi-arid (Barthel et al., 1990). One might argue that this is an unusual deposit in that it represents a marine, lagoonal environment with many fossils of terrestrial origin. However, allochthonous dinosaur assemblages are well-known from several fully marine deposits, including the Callovian to Oxfordian (Middle to Late Jurassic) Oxford Clay and the Kimmeridgian (Late Jurassic) Kimmeridge Clay, both in England (Martill, 1988b). Dinosaurs are known from both of these organic-rich mudrocks and, although the data sets are small, dinosaurs are represented in both cases by most of the major groups (Martill, 1988b). Similar numbers of dinosaur specimens have been recorded from these Jurassic marine mudrock formations, the Santana Formation, and the Solnhofen Limestone. Thus, it is surprising that all the approximately ten dinosaur specimens collected from Solnhofen, even after 150 years, are theropods. Similarly, we know of about eight specimens, all of them theropods, from the Santana Formation. The Oxford Clay of Peterborough, England has yielded about ten dinosaur specimens, representing seven taxa, only two of which are theropods. The Kimmeridge Clay of southern England has yielded nine taxa (total specimen count is not known) of which only two are theropods. One of these theropods is an undescribed partial skeleton. In all cases, these faunas are considered allochthonous, the dinosaurs probably having drifted into marginal marine environments from river systems draining local hinterlands. Despite the small numbers of specimens, the terrestrial environments adjacent to the Santana Formation and the Solnhofen Limestone do appear to have supported at most limited numbers of herbivorous dinosaurs.

\section{ADDENDUM}

After this paper had been accepted for publication, two published studies appeared which included discussions of compsognathid systematics and phylogeny (Rauhut, 2003; Hwang et al., 2004) While both employed a more thorough analysis of character distribution within Coelurosauria than the present study, both supported compsognathid monophyly and inclusion within the clade of the same taxa included here. Though Rauhut (2003) argued that the holotype of Mirischia should be regarded as Compsognathinae indet., he also noted that it probably represented a distinct taxon. Hwang et al. (2004) described the new compsognathid Huaxiagnathus orientalis from the Yixian Formation (probably the most basal compsognathid) and agreed that Mirischia is a compsognathid, albeit one too incomplete to include in their analysis. 